\title{
Peran Mikroorganisme Lokal Rebung Bambu Terhadap Pertumbuhan Dan Kandungan Protein Tanaman Kedelai
}

\author{
Nerty Soverda dan Evita \\ Jurusan Agroekoteknologi Fakultas Pertanian Universitas Jambi \\ Email corresponding author: nsoverda@yahoo.com
}

\begin{abstract}
ABSTRAK
Kedelai (Glycine Max L. Merrill) merupakan tanaman pangan ketiga setelah padi dan jagung di Indonesia. Umumnya, kedelai dimanfaatkan sebagai bahan makanan manusia, pakan ternak maupun bahan baku industri. Namun, terdapat beberapa masalah dalam pengelolaan penanamannya, salah satunya adalah kondisi lahan yang tidak optimal untuk mendukung pertumbuhan kedelai, terutama di Jambi. Hal ini karena lahan di jambi umumnya didominasi oleh tanah ultisol yang tingkat kesuburan yang rendah. Tujuan khusus dari penelitian yang direncanakan adalah mempelajari peran mol rebung bambu terhadap pertumbuhan dan kandungan protein tanaman kedelai. Penelitan akan dilaksanakan dengan menggunakan Rancangan Acak Kelompok (RAK) dengan satu faktor yaitu pemberian berbagai konsentrasi MOL rebung bambu dengan 6 taraf perlakuan, yaitu : mo: tanpa perlakuan Mol rebung bambu, $\mathrm{m}_{1} 50 \mathrm{ml} / \mathrm{L}$ air, $\mathrm{m}_{2}$ : $75 \mathrm{ml} / \mathrm{L}$ air, $\mathrm{m}_{3}: 100 \mathrm{ml} / \mathrm{L}$ air, m4: $125 \mathrm{ml} / \mathrm{L}$ air dan m5: $150 \mathrm{ml} / \mathrm{L}$ air. Variabel yang diamati tinggi tanaman, jumlah polong berisi per tanaman, bobot biji per tanaman, bobot 100 biji, hasil per plot dan kandungan protein kedelai. Berdasarkan hasil pengamatan maka dapat disimpulkan bahwa Pemberian MOL rebung bambu dapat memberikan pengaruh yang nyata terhadap bobot 100 biji pertanaman tetapi tidak memberikan pengaruh pada variabel lainnya, akan tetapi pemberian MOL memiliki kecendrungan untuk meningkatkan pertumbuhan dan hasil tanaman kedelai. Disamping itu didapat bahwa pemberian MOL rebung bambu dengan konsentrasi $75 \mathrm{ml} / \mathrm{L}$ air merupakan konsentrasi terbaik dalam upaya meningkatkan hasil tanaman kedelai.
\end{abstract}

Kata Kunci: Kedelai, Mol Rebung, Protein

\section{PENDAHULUAN}

Salah satu komoditas pangan yang penting dalam rangka ketahanan pangan penduduk Indonesia adalah kedelai. Kedelai digunakan sebagai bahan baku pembuatan tempe dan tahu yang merupakan makanan yang banyak dikonsumsi oleh masyarakat Indonesia serta sebagai bahan pembuatan makanan dan minuman yang memiliki nilai gizi tinggi. Kedelai merupakan sumber protein nabati yang bernilai gizi tinggi, setiap $100 \mathrm{~g}$ tanaman kedelai memiliki kandungan kalori 331 kal, protein 34,9 g dan lemak 18,1 g. Secara keseluruhan, nilai protein kedelai cukup 
baik,walaupun masih berada di bawah protein susu sapi atau telur ayam (Pitojo, 2003).

Luas areal panen tanaman kedelai di Provinsi Jambi pada tahun 2015 - 2016 mengalami peningkatan areal sebesar 3.637 Ha dengan peningkatan produksi sebesar 4.606 ton. Namun pada tahun 2016 - 2017 mengalami penurunan luas areal sebesar 1.271,8 Ha diikuti dengan penurunan produksi sebesar 413 ton.

Rendahnya produksi kedelai disebabkan oleh beberapa faktor diantaranya adalah iklim, hama dan penyakit, serta teknik budidaya yang diterapkan sehingga diperlukan inovasi-inovasi baru yang dapat meningkatkan produksi kedelai. Salah satu usaha yang dapat dilakukan untuk meningkatkan produksi kedelai yang ditanam pada lahan ultisol yang daya pegang airnya sangat rendah adalah dengan mengaplikasikan mol rebung bambu sebagai pupuk organik.

Kedelai merupakan salah satu tanaman pangan penting di Indonesia setelah beras dan jagung. Menurut Oktaviani dan Haryono (2013), setiap 100 gram kedelai mengandung 34,90 gram protein, 18,10 gram lemak, 34,80 gram karbohidrat dengan nilai 331 kalori. Kedelai merupakan salah satu tanaman kacang-kacangan andalan nasional yang menunjang program diversifikasi pangan dan mendukung ketahanan pangan nasional. Kedelai banyak dimanfaatkan sebagai bahan baku olahan makanan, pakan ternak maupun bahan baku industri manufaktur.

Kebutuhan kedelai setiap tahun akan selalu meningkat seiring dengan pertambahan penduduk. Oleh karena itu, diperlukan suplai kedelai tambahan yang harus diimpor karena produksi dalam negeri belum dapat mencukupi kebutuhan tersebut. Tercatat impor kedelai pada Januari sampai Juni 2018 mencapai 1,17 juta ton (Badan Pusat Statistik, 2018). Menurut Data Pusdatin Kementrian Pertanian (2018), konsumsi kedelai Nasional 2018 mencapai 3,05 juta ton sedangkan produksi hanya mencapai 864.000 ton, sehingga perlu adanya penambahan pasokan kedelai dalam negeri. Untuk mengatasi kekurangan pasokan kedelai maka diperlu suatu usaha untuk meningkatkan produksi kedelai nasional.

Dalam upaya pengembangan tanaman kedelai di Jambi ditemukan kendala yaitu ketersediaan lahan yang sesuai untuk tanaman kedelai. Jenis tanah yang cocok untuk usaha budidaya tanaman kedelai adalah tanah Alluvial, Grumusol, Andosol, Latosol dan Regusol yang subur, gembur, kaya akan bahan organik, tidak mudah tergenang atau tidak terlalu basah, bebas nematoda dan penyakit menular dalam tanah. Namun, salah satu kendala dalam pengelolaan Ultisol adalah kandungan bahan organiknya yang sangat rendah yaitu kurang dari $2 \%$. Bahan organik tanah menyusun 5\% bobot total tanah, meskipun hanya sedikit tetapi memegang peranan penting dalam menentukan kesuburan suatu tanah, baik secara fisik, kimiawi, maupun secara biologis. Sehingga perlu adanya penambahan bahan organik pada tanah.

Untuk meningkatkan pertumbuhan dan produksi tanaman kedelai pada Ultisol salah satu cara yang bisa digunakan adalah memberikan bahan organik yang mengandung mikroorganisme seperti Mol Rebung. Rebung adalah salah satu 
jenis tanaman yang potensial untuk diekstrak menjadi mol karena tingginya kandungan zat pengatur tumbuh. Mikroorganisme lokal mengandung zat yang dapat merangsang pertumbuhan tanaman dan zat yang mampu mendorong perkembangan tanaman seperti Giberelin, Sitokinin, Auksin dan Inhibator (Mauludin, 2009).

Menurut Maspary (2012), larutan MOL rebung bambu mempunyai kandungan $\mathrm{C}$ organik dan giberelin yang tinggi sehingga mampu merangsang pertumbuhan tanaman, larutan MOL rebung bambu juga mengandung Azotobacter dan Azospirillum, mikroorganisme ini sangat penting membantu pertumbuhan tanaman. Menurut hasil penelitian Rakhmadi et al., 2018 dosis anjuran untuk pengaplikasian mol rebung bambu sebagai pupuk daun adalah 65 $\mathrm{ml} / \mathrm{l}$ air.

Dengan adanya upaya pengembangan dan peningkatan produksivitas tanaman kedelai melalui pemanfaatan bahan organik yang mengandung mikroorganisme seperti Mol Rebung maka diharapkan dapat memantapkan dan mewujudkan Provinsi Jambi sebagai sentra produksi kedelai nasional. Disamping itu, dengan mengoptimalkan pemanfaatan lahan kering dan maka diharapkan dapat meningkatkan pendapatan bagi petani.

\section{METODE PENELITIAN}

Penelitan dilaksanakan dengan menggunakan Rancangan Acak Kelompok (RAK) dengan satu faktor yaitu pemberian berbagai konsentrasi MOL rebung bambu dengan 6 taraf perlakuan, yaitu : $\mathrm{m}_{0}$ : tanpa perlakuan Mol rebung bambu, $\mathrm{m}_{1} 50$ $\mathrm{ml} / \mathrm{L}$ air, $\mathrm{m}_{2}: 75 \mathrm{ml} / \mathrm{L}$ air, $\mathrm{m}_{3}: 100 \mathrm{ml} / \mathrm{L}$ air, $\mathrm{m}_{4} \quad: 125 \mathrm{ml} / \mathrm{L}$ air dan $\mathrm{m}_{5}$ $150 \mathrm{ml} / \mathrm{L}$ air.

Percobaan ini terdiri dari 6 perlakuan dan masing - masing perlakuan di ulang sebanyak 4 kali sehingga di dapatkan 24 petak percobaan. Ukuran petak percobaan $2 \times 1,5 \mathrm{~m}$ dan memiliki jarak tanam $30 \times 40 \mathrm{~cm}$, sehingga populasi tanaman setiap petakan 25 tanaman dan sampel yang akan diamati sebanyak 4 tanaman setiap petak percobaan. Pelaksanaan Penelitian meliputi pembuatan Mol Rebung Bambu, Persiapan Benih, Persiapan Lahan, Penanaman, pemupukan, Pemberian Perlakuan, Pemeliharaan Tanaman dan Pemanenan.

Variabel Pengamatan meliputi Tinggi Tanaman, Jumlah polong berisi per tanaman, Bobot biji per tanaman (gram), Bobot 100 biji (gram), Hasil per plot dan Kandungan Protein. Analisis Data Untuk mengetahui pengaruh perlakuan dilakukan analisis secara statistik dengan sidik ragam. Jika terdapat pengaruh yang nyata di lanjutkan dengan uji Duncan Multiple Range Test (DMRT) pada taraf $\alpha=5$ $\%$. 


\section{HASIL DAN PEMB AHAS A N}

\section{Tinggi Tanaman}

Perlakuan mol rebung bambu tidak berpengaruh terhadap tinggi tanaman kedelai, tetapi menyebabkan perubahan pada tinggi tanaman kedelai. Rata-rata tinggi tanaman dan perubahan tinggi tanaman yang terjadi pada tanaman kedelai melalui pemberian beberapa dosis mol rebung bambu dapat dilihat pada Tabel 1 berikut.

Tabel 1. Rata-rata tinggi tanaman dan perubahan tinggi tanaman kedelai pada pemberian beberapa dosis mol rebung bambu

\begin{tabular}{|c|c|c|c|c|}
\hline No. & Perlakuan & $\begin{array}{c}\text { Tinggi } \\
\text { Tanaman }\end{array}$ & NR & Perubahan (\%) \\
\hline 1 & $\mathrm{M}_{0}(\tan p a \mathrm{Mol})$ & $16,87 \mathrm{a}$ & - & - \\
\hline 2 & $\mathrm{M}_{1}(50 \mathrm{ml} / \mathrm{L}$ air $)$ & $17,51 \mathrm{a}$ & 103,8 & 3,8 \\
\hline 3 & $\mathrm{M}_{2}(75 \mathrm{ml} / \mathrm{L}$ air $)$ & 16,29 a & 96,6 & $-3,4$ \\
\hline 4 & $\mathrm{M}_{3}(100 \mathrm{ml} / \mathrm{L}$ air $)$ & $15,45 \mathrm{a}$ & 91,6 & $-8,4$ \\
\hline 5 & $\mathrm{M}_{4}(125 \mathrm{ml} / \mathrm{L}$ air $)$ & 15,18 a & 89,9 & $-10,1$ \\
\hline 6 & $\mathrm{M}_{5}(150 \mathrm{ml} / \mathrm{L}$ air $)$ & $14,28 \mathrm{a}$ & 84,6 & $-15,4$ \\
\hline
\end{tabular}

Keterangan : Angka rata-rata pada kolom yang sama yang diikuti oleh huruf yang sama, tidak berbeda nyata berdasarkan uji BNT (0.05). NR= Nilai Relatif (\% kontrol).

Dari Tabel 1 diatas dapat dilihat bahwa tinggi tanaman tidak dipengaruhi oleh perlakuan mol rebung bambu. Namun kecenderungan yang terjadi menunjukkan terjadinya perubahan, dimana terjadinya peningkatan sebesar 3,8\% pada $\mathrm{M}_{1}$, namun perlakuan $\mathrm{M}_{2}, \mathrm{M}_{3}, \mathrm{M}_{4}$ dan $\mathrm{M}_{5}$ terjadi penurunan dibandingkan tanpa pemberian mol rebung bambu yaitu masing-masing sebesar 3,4\%, 8,4\%, 10,1\% dan $15,4 \%$.

\section{Jumlah polong berisi per tanaman}

Pada peubah jumlah polong berisi per tanaman juga tidak terdapat pengaruh yang nyata. Terlihat adanya penurunan nilai pada perlakuan $\mathrm{M}_{3}$ dan peningkatan pada perlakuan lainnya. Perubahan tersebut dapat dilihat pada Tabel 2 berikut. 
Tabel 2. Rata-rata jumlah polong berisi per tanaman dan perubahan jumlah polong berisi per tanaman kedelai pada pemberian beberapa dosis mol rebung bambu

\begin{tabular}{llccc}
\hline No & Perlakuan & $\begin{array}{c}\text { Jumlah polong } \\
\text { berisi per tanaman }\end{array}$ & NR & $\begin{array}{c}\text { Perubahan } \\
(\%)\end{array}$ \\
\hline 1 & $\mathrm{M}_{0}($ tanpa Mol) & $57,00 \mathrm{a}$ & - & - \\
2 & $\mathrm{M}_{1}(50 \mathrm{ml} / \mathrm{L}$ air $)$ & $61,31 \mathrm{a}$ & 107,5 & 7,5 \\
3 & $\mathrm{M}_{2}(75 \mathrm{ml} / \mathrm{L}$ air $)$ & $70,62 \mathrm{a}$ & 123,9 & 23,9 \\
4 & $\mathrm{M}_{3}(100 \mathrm{ml} / \mathrm{L}$ air $)$ & $54,87 \mathrm{a}$ & 96,3 & $-3,7$ \\
5 & $\mathrm{M}_{4}(125 \mathrm{ml} / \mathrm{L}$ air $)$ & $62,50 \mathrm{a}$ & 109,6 & 9,6 \\
6 & $\mathrm{M}_{5}(150 \mathrm{ml} / \mathrm{L}$ air $)$ & $56,56 \mathrm{a}$ & 99,2 & 0,8 \\
\hline
\end{tabular}

Keterangan : Angka rata-rata pada kolom yang sama yang diikuti oleh huruf yang sama, tidak berbeda nyata berdasarkan uji BNT (0.05). NR = Nilai Relatif (\% kontrol).

Pada Tabel 2 diatas terlihat bahwa pemberian mol rebung tidak berpengaruh nyata terhadap jumlah polong berisi per tanaman. Perubahan yang terjadi menunjukkan bahwa perlakuan $\mathrm{M}_{3}$ mengalami penurunan dibandingkan tanpa mol yaitu sebesar 3,7\%. Sementara perlakuan lainnya menunjukkan peningkatan dan peningkatan tertinggi terlihat pada perlakuan $\mathrm{M}_{2}$ yaitu sebesar 23,9\%.

\section{Bobot biji per tanaman}

Pemberian mol rebung tidak memberikan pengaruh yang nyata terhadap bobot biji per tanaman. Namun terjadi perubahan-perubahan sebagaimana terlihat pada Tabel 3 berikut.

Tabel 3. Rata-rata bobot biji per tanaman dan perubahan bobot biji per tanaman kedelai pada pemberian beberapa dosis mol rebung bambu

\begin{tabular}{llcrc}
\hline No. & Perlakuan & $\begin{array}{c}\text { Bobot biji per } \\
\operatorname{tanaman}(\mathrm{g})\end{array}$ & NR & $\begin{array}{c}\text { Perubahan } \\
(\%)\end{array}$ \\
\hline 1 & $\mathrm{M}_{0}(\operatorname{tanpa~Mol})$ & $17,50 \mathrm{a}$ & - & - \\
2 & $\mathrm{M}_{1}(50 \mathrm{ml} / \mathrm{L}$ air $)$ & $19,25 \mathrm{a}$ & 110,0 & 10,0 \\
3 & $\mathrm{M}_{2}(75 \mathrm{ml} / \mathrm{L}$ air $)$ & $22,00 \mathrm{a}$ & 125,7 & 25,7 \\
4 & $\mathrm{M}_{3}(100 \mathrm{ml} / \mathrm{L}$ air $)$ & $16,75 \mathrm{a}$ & 95,7 & $-4,3$ \\
5 & $\mathrm{M}_{4}(125 \mathrm{ml} / \mathrm{L}$ air $)$ & $18.00 \mathrm{a}$ & 102,8 & 2,8 \\
6 & $\mathrm{M}_{5}(150 \mathrm{ml} / \mathrm{L}$ air $)$ & $18,00 \mathrm{a}$ & 102,8 & 2,8 \\
\hline
\end{tabular}

Keterangan : Angka rata-rata pada kolom yang sama yang diikuti oleh huruf yang sama, tidak berbeda nyata berdasarkan uji BNT (0.05). NR = Nilai Relatif (\% kontrol).

Pada Tabel 3 diatas terlihat bahwa tidak adanya pengaruh yang nyata pada bobot biji per tanaman dengan pemberian mol rebung bambu. Perlakuan $\mathrm{M}_{3}$ terlihat menurunkan bobot biji per tanaman dinandingkan tanpa pemberian mol rebung 
yaitu sebesar 4, 3\%. Perlakuan lainnya terlihat meningkatkan bobot biji per tanaman dan peningkatan terbesar terlihat pada perlakuan $\mathrm{M}_{2}$ yaitu sebesar $25,7 \%$.

\section{Bobot 100 biji}

Pada peubah bobot 100 biji, perlakuan mol rebung memberikan pengaruh nyata. Perlakuan $\mathrm{M}_{1}$ berbeda nyata dibandingkan dengan perlakuan lainnya, kecuali pada perlakuan $\mathrm{M}_{3}$. Perubahan yang terjadi dapat dilihat pada Tabel 4 berikut ini.

Tabel 4. Rata-rata bobot 100 biji dan perubahan bobot 100 biji kedelai pada pemberian beberapa dosis mol rebung bambu

\begin{tabular}{clccc}
\hline No. & Perlakuan & Bobot 100 biji (g) & NR & $\begin{array}{c}\text { Perubahan } \\
(\%)\end{array}$ \\
\hline 1 & M0 (tanpa Mol) & $12,75 \mathrm{a}$ & - & - \\
2 & M $_{1}(50 \mathrm{ml} / \mathrm{L}$ air $)$ & $15,00 \mathrm{~b}$ & 117,6 & 17,6 \\
3 & $\mathrm{M}_{2}(75 \mathrm{ml} / \mathrm{L}$ air $)$ & $15,50 \mathrm{~b}$ & 121,6 & 21,6 \\
4 & $\mathrm{M}_{3}(100 \mathrm{ml} / \mathrm{L}$ air $)$ & $14,00 \mathrm{ab}$ & 109,8 & 9,8 \\
5 & $\mathrm{M}_{4}(125 \mathrm{ml} / \mathrm{L}$ air $)$ & $15,25 \mathrm{~b}$ & 119,6 & 19,6 \\
6 & $\mathrm{M}_{5}(150 \mathrm{ml} / \mathrm{L}$ air $)$ & $14,75 \mathrm{~b}$ & 115,7 & 15,7 \\
\hline
\end{tabular}

Keterangan : Angka rata-rata pada kolom yang sama yang diikuti oleh huruf yang sama, tidak berbeda nyata berdasarkan uji BNT (0.05). $\mathrm{NR}=$ Nilai Relatif (\% kontrol).

Pada Tabel 4 diatas menunjukkan bahwa pemberian mol rebung memberikan beda yang nyata antara tanpa pemberian mol dengan pemberian mol rebung, kecuali dengan perlakuan $\mathrm{M}_{3}$ tidak berbeda nyata. Pada semua perlakuan terlihat adanya peningkatan bobot 100 biji dibandingkan dengan tanpa pembrian mol. Peningkatan bobot 100 biji untuk masing-masing perlakuan adalah sebesar 17,6\%, 21,6\%, 9,8\%, 19,6\%, dan 15,7\% untuk perlakuan $\mathrm{M}_{1}, \mathrm{M}_{2}, \mathrm{M}_{3}, \mathrm{M}_{4}$ dan $\mathrm{M}_{5}$.

\section{Kandungan Protein}

Perlakuan pemberian mol rebung bambu tidak berpengaruh terhadap kandungan protein untuk perlakuan untuk perlakuan $M_{1}, M_{2}, M_{3}$ dan $M_{4}$, tetapi berpengaruh nyata terhadap $\mathrm{M}_{5}$. Terjadi penurunan kandungan protein untuk semua perlakuan kecuali pada perlakuan 5, terjadi peningkatan. Rata-rata Kandungan Protein dan perubahan yang terjadi pada tanaman kedelai melalui pemberian beberapa dosis mol rebung bambu dapat dilihat pada Tabel 5 berikut.

Tabel 5. Rata-rata Kandungan Protein dan perubahan Kandungan Protein kedelai pada pemberian beberapa dosis mol rebung bambu

\begin{tabular}{|c|c|c|c|c|}
\hline No. & Perlakuan & Kandungan & NR & Perubahan \\
\hline
\end{tabular}




\begin{tabular}{lllcc}
\hline 1 & $\mathrm{M}_{0}($ tanpa Mol) & $14,14 \mathrm{a}$ & - & - \\
2 & $\mathrm{M}_{1}(50 \mathrm{ml} / \mathrm{L}$ air $)$ & $13,12 \mathrm{a}$ & 92,8 & $-7,2$ \\
3 & $\mathrm{M}_{2}(75 \mathrm{ml} / \mathrm{L}$ air $)$ & $13,92 \mathrm{a}$ & 98,4 & $-1,6$ \\
4 & $\mathrm{M}_{3}(100 \mathrm{ml} / \mathrm{L}$ air $)$ & $13,19 \mathrm{a}$ & 93,3 & $-6,7$ \\
5 & $\mathrm{M}_{4}(125 \mathrm{ml} / \mathrm{L}$ air $)$ & $10,59 \mathrm{a}$ & 74,9 & $-1,3$ \\
6 & $\mathrm{M}_{5}(150 \mathrm{ml} / \mathrm{L}$ air $)$ & $17,30 \mathrm{~b}$ & 122,3 & 22,3 \\
\hline
\end{tabular}

Keterangan : Angka rata-rata pada kolom yang sama yang diikuti oleh huruf yang sama, tidak berbeda nyata berdasarkan uji BNT (0.05). NR = Nilai Relatif (\% kontrol).

Pada Tabel 5 diatas menunjukkan bahwa pemberian mol rebung bambu tidak memberikan beda yang nyata pada perlakuan yang diberikan, kecuali pada perlakuan $\mathrm{M}_{5}$. Semua perlakuan mengalami penurunan pada kandungan protein kecuali pada perlakuan $\mathrm{M}_{5}$, terjadi peningkatan sebesar 22,3\%.

\section{PEMBAHASAN}

Pertumbuhan dan perkembangan tanaman selain dipengaruhi faktor internal juga dipengaruhi oleh ketersediaan unsur hara dalam tanah, seperti unsur $\mathrm{N}$ dan $\mathrm{P}$. Unsur hara $\mathrm{N}$ sangat berperan dalam merangsang pertumbuhan tanaman dan unsur $\mathrm{P}$ berperan untuk memperkuat pertumbuhan tanaman dan mempercepat pembungaan serta berperan dalam pembentukan biji. Dari hasil analisis kimia, mol rebung bambu mengandung $\mathrm{N}$ total $307 \mathrm{mg} / \mathrm{L}$ dan Phosphat $142 \mathrm{mg} / \mathrm{L}$.

Berdasarkan penelitian dan analisis data yang dilakukan menunjukkan bahwa pemberian MOL rebung bambu pada tanaman kedelai tidak berbeda nyata terhadap parameter tinggi tanaman kedelai, jumlah polong berisi per tanaman, dan bobot biji pertanaman, sedangkan parameter kandungan protein pemberian mol rebung bambu memberikan pengaruh yang nyata pada tanaman kedelai. Menurut Jumaidi (2018) bahwa mol rebung bambu merupakan cairan hasil fermentasi bahan organik yang tidak hanya mengandung unsur hara makro dan mikro tetapi juga berbagai macam asam amino, fitohormon, mikroba menguntungkan, vitamin, nutrisi esensial dan berperan dalam menstimulasikan pertumbuhan mikroba di rizosfer dan filosfer tanaman.

Pemberian Mol Rebung bambu tidak berpengaruh nyata terhadap tinggi tanaman. Berdasarkan analisis MOL rebung kandungan unsur N 307 mg/L, unsur P 142 mg/l, dan pH 4,10. Hal tersebut diduga karena kandungan unsur hara yang terkandung dalam Mol rebung bambu dapat bekerja dengan baik pada dosis Mol $50 \mathrm{ml} / \mathrm{L}$ air dan sudah mampu menyediakan unsur hara yang baik seperti nitrogen dan hormone giberelin dalam pertumbuhan tinggi tanaman. Sejalan dengan pendapat Dhani et al., (2014) yang menyatakan bahwa unsur nitrogen sangat dibutuhkan tanaman untuk mensintesa asam - asam amino dan protein, terutama pada titik- titik tumbuh tanaman sehingga mempercepat proses pertumbuhan 
tanaman seperti pembelahan sel dan perpanjangan sel sehingga meningkatkan tinggi tanaman. Selain itu juga terdapat giberelin $\left(\mathrm{GA}_{3}\right)$ yang juga dapat memacu pertumbuhan dan menigkatkan hasil produktivitas tanaman. Santoso dan Fatma (2004) menyatakan, bahwa giberelin berperan dalam pemanjangan batang, pertumbuhan tunas, merangsang pembungaan dan perkembangan buah.

Pemberian mol rebung bambu tidak berbeda nyata terhadap jumlah polong berisi per tanaman kedelai. Pemberian mol dengan konsentrasi yang berbeda tidak berpengaruh terhadap jumlah polong. Tetapi terdapat kecendrungan Pemberian mol rebung bambu dengan dosis $75 \mathrm{ml} / \mathrm{L}$ air memiliki jumlah polong tetinggi sebesar 70,62 gram dan mampu meningkatkan jumlah polong berisi per tanaman sebesar $23,89 \%$ dibandingkan tanpa perlakuan. Hal tersebut dikarenakan kandungan unsur hara pada mol rebung sudah lengkap. Pada konsentrasi $75 \mathrm{ml} / \mathrm{L}$ air diduga mol telah menyediakan unsur hara esensial yang dibutuhkan oleh tanaman kedelai untuk pembentukan polong. Asie, (2013) melaporkan bahwa jumlah polong isi pertanaman kedelai lebih banyak sejalan dengan lebih tingginya takaran pupuk hayati majemuk cair dan juga diduga kandungan unsur hara P yang terkandung dalam mol rebung bamboo sudah mencukupi kebutuhan tanaman, sehingga unsur tersebut sudah dapat diserap oleh tanaman sebagai pengaktif enzim untuk fotosintesis yang hasilnya berupa fotosintat. Menurut pendapat Falodun et.al, (2015) dalam Arifin, (2018) unsur hara P merupakan komponen penyusun membrane sel tanaman, penyusun enzim - enzim dan juga berperan dalam sintesis protein terutama pada jaringan hijau, sintesis karbohidrat serta memacu pembentukan biji.

Pemberian mol rebung bambu tidak berbeda nyata antar perlakuan maupun dengan tanpa perlakuan terhadap bobot biji per tanaman kedelai (Tabel 5). Hasil pemberian mol rebung bambu tertinggi terhadap bobot biji per tanaman yaitu pada pemberian $75 \mathrm{ml} / \mathrm{L}$ air sebesar 22 gram dan meningkatkan hasil 25,7\% dibandingkan tanpa perlakuan, sedangkan hasil terendah pada pemberian mol rebung bambu pada dosis $100 \mathrm{ml} / \mathrm{L}$ air yaitu 16,75 gram. . Hal ini dikarenakan berat biji berkaitan erat dengan laju asimilasi bersih, yang mana efisiensi tanaman dalam memanfaatkan hasil fotosintesis akan mempengaruhi berat biji yang dihasilkan. Sabilo, (2018) dalam Arifin, (2018), menyatakan bahwa selama pengisian biji sebagian besar hasil asimilasi yang baru terbentuk maupun yang tersimpan akan digunakan untuk meningkatkan berat biji tanaman dan di duga juga kandungan unsur hara yang terkandung dalam mol rebung bamboo sudah mencukupi kebutuhan tanaman, terutama unsur hara $\mathrm{P}$ karena unsur hara $\mathrm{P}$ (Fosfor) sangat berperan aktif dalam mentransfer energi di dalam sel, mengubah karbohidrat, dan meningkatkan efisiensi kerja kloroplas (Hakim dalam Dhani, 2014) sejalan dengan pendapat (Falodun et.al, 2015 dalam Arifin, 2018 ) unsur hara P (Fosfat) merupakan komponen penyusun membrane sel tanaman, penyusun enzim - enzim dan juga berperan dalam sintesis protein terutama pada jaringan hijau, sintesis karbohidrat serta memacu pembentukan biji. 
Pemberian mol rebung bambu berpengaruh nyata terhadap bobot 100 biji tanaman kedelai (tabel 6). Hasil tanpa perlakuan berbeda nyata dengan perlakuan $50 \mathrm{ml} / \mathrm{L}$ air, $75 \mathrm{ml} / \mathrm{L}$ air, $125 \mathrm{ml} / \mathrm{L}$ air, dan $150 \mathrm{ml} / \mathrm{L}$ air, namun tidak berbeda nyata dengan perlakuan $100 \mathrm{ml} / \mathrm{L}$ air. Pemberian mol rebung bambu dapat meningkatkan bobot 100 biji tanaman kedelai sebesar 9,8\% - 21,56\% dibandingkan tanpa pemberiaan mol rebung bambu. Hal ini dikarenakan berat 100 biji berkaitan erat dengan laju asimilasi bersih, yang mana efisiensi tanaman dalam memanfaatkan hasil fotosintesis akan mempengaruhi berat biji yang dihasilkan. Sabilo, (2018) dalam Arifin, (2018) menyatakan bahwa selama pengisian biji sebagian besar hasil asimilasi yang baru terbentuk maupun yang tersimpan akan digunakan untuk meningkatkan berat biji tanaman. Peningkatan berat 100 biji ini juga dipengaruhi oleh banyak nya unsur hara yang diberikan seperti unsur hara N,P, dan K. Sejalan dengan pendapat Firmansyah et.al, (2015) dalam Arifin, (2018) yang menyatakan bahwa pemeberian pupuk dapat memberikan hasil yang diharapkan apabila konsentrasi yang diberikan tidak melebihi batas optimum dan konsentrasi yang dianjurkan.

Hasil analisis pemberian mol rebung bambu terhadap hasil per plot tanaman kedelai berpengaruh tidak nyata (Tabel 7). Nilai tertinggi pada pemberian mol rebung bambu dengan dosis $75 \mathrm{ml} / \mathrm{L}$ air sebesar 413,25 gram dan meningkatkan hasil $16,32 \%$ dibandingkan tanpa perlakuan, sedangkan nilai terendah pada pemberian dengan dosis $125 \mathrm{ml} / \mathrm{L}$ air yaitu 309,75 gram. Hal ini diduga pada pemberian mol rebung bambu dengan dosis $75 \mathrm{ml} / \mathrm{L}$ dapat menyumbangkan unsur hara dengan baik untuk tanaman, serta berkaitan erat dengan laju asimilasi bersih, yang mana efisiensi tanaman dalam memanfaatkan hasil fotosintesis akan mempengaruhi berat biji tanaman. Sejalan dengan pendapat Vankatesarlu dan Rao, (1983) dalam Firmansyah et al., (2015) bahwa dalam mol rebung bambu menghasilkan bakteri Azotobacter dan Azospirillum merupakan bakteri yang menguntungkan bagi tanaman yang hidup di dalam tanah sebagai percepatan penyedia hara dan juga sebagai sumber bahan organik tanah. Sehingga unsur hara yang tersedia di dalam tanah cukup bagi tanaman untuk pertumbuhan dan hasil tanaman.

\section{KESIMPULAN DAN SARAN}

Berdasarkan hasil pengamatan maka dapat disimpulkan bahwa Pemberian MOL rebung bambu dapat memberikan pengaruh yang nyata terhadap bobot 100 biji pertanaman tetapi tidak memberikan pengaruh pada variabel lainnya, akan tetapi pemberian MOL memiliki kecendrungan untuk meningkatkan pertumbuhan dan hasil tanaman kedelai. Pemberian MOL rebung bambu dengan konsentrasi $75 \mathrm{ml} / \mathrm{L}$ air merupakan konsentrasi terbaik dalam upaya meningkatkan hasil tanaman kedelai. 


\section{UCAPAN TERIMA KASIH}

Terima kasih kami sampaikan Lembaga Penelitian dan Pengabdian Kepada Masyarakat Universitas Jambi dan Fakultas Pertanian Universitas Jambi yang telah membiayai penelitian ini pada Tahun Anggaran 2020.

\section{DAFTAR PUSTAKA}

Ansoruddin, Safruddin dan R. Sinaga. 2017. Respon pertumbuhan dan produksi tanaman selada merah (Red lettuce) terhadap pemberian bokashi eceng gondok dan bokashi ampas tebu. Jurnal Penelitian Pertanian BERNAS 13(1):66-71.

Chaniago, N., D.W. Purba dab A. Utama. 2017. Respon pemberian pupuk organik cair (POC) bonggol pisang dan sistem jarak tanam pertumbuhan dan produksi kacang hijau (Vigna radiata L. Wilczek.). Jurnal Penelitian Pertanian BERNAS 13(2):1-8.

Direktorat Budidaya Serealia. 2013. Kebijakan Direktorat Jenderal Tanaman Pangan dalam Pengembangan Komoditas Jagung, Sorgum dan Gandum. Direktorat Jenderal Tanaman Pangan. Kementrian Pertanian Republik Indonesia. Jakarta.

Direktorat Budidaya Serealia. 2016. Laporan Tahunan Direktorat Budidaya Serealia Tahun 2015. Kementrian Pertanian Republik Indonesia. Jakarta.

Hasibuan, S., R. Mawarni dan R. Hendriadi. 2017. Respon pemberian pupuk bokashi ampas tebu dan pupuk bokashi eceng gondok terhadap pertumbuhan dan produksi tanaman kedelai (Glycine max (L) Merril.). Jurnal Penelitian Pertanian BERNAS 13(2):59-64.

Hayati, E., T. Mahmud dan R. Fazil. 2012. Pengaruh jenis pupuk organik dan varietas terhadap pertumbuhan dan hasil tanaman cabai (Capsicum annum L.). Jurnal Floratek 7(1):173-181.

Ilyasa, M., S. Hutapea dan A. Rahman. 2016. Respon pertumbuhan dan produksi tanaman cabai rawit (Capsicum frutescens L.) terhadap pemberian kompos dan biochar dari limbah ampas tebu. Jurnal Agrotekma 2(2):81-92..

Musnamar, E.I. 2003. Pembuatan dan Aplikasi Pupuk Organik Padat. Penebar Swadaya. Jakarta.

Prasetyo, B.H. dan D.A. Suriadikarta. 2006. Karakteristik, potensi, dan teknologi pengolahan tanah ultisol untuk pengembangan pertanian lahan kering di Indonesia. Jurnal Litbang Pertanian 25(2):39-47.

Roidah, I. S. 2013. Manfaat penggunaan pupuk organic untuk kesuburan tanah. Jurnal Universitas Tulungagung BONOWORO 1(1):30-42.

Ruhukail, N.L. 2011. Pengaruh penggunaan EM4 yang dikulturkan pada bokashi dan pupuk anorganik terhadap produksi tanaman kacang tanah (Arachis 
hypogea L.) di kampung wanggar kabupaten nabire. Junal Agroforestri 4(2):114-120.

Suriadikarta, D. A., dan R. D. M. Simanungkalit. 2006. Pupuk Organik dan Pupuk Hayati. Balai Besar Penelitian dan Pengembangan Sumberdaya Lahan Pertanian. Bogor.

Tamtomo, F., S. Rahayu dan A. Suyanto. 2015. Pengaruh aplikasi kompos jerami dan abu sekam padi terhadap produksi dan kadar pati ubi jalar. Jurnal Agrosains 12(2):1-7. 